\title{
Studi Budaya Pada Eksistensi Pelayaran (7 Hari Kematian) di Desa Sukarema Lombok Timur
}

\author{
Husnayati, Syahrul Amar, Zidni \\ Universitas Hamznwadi \\ husnayati23@gamil.com
}

\begin{abstract}
Abstrak
Kebudayaan memiliki bentuk tersendiri dalam suatu masyarakat. Di Desa Sukarema Lombok Timur terdapat kebiasaan masyarakt dalam menghormati keluarga yang sudah meninggal dunia yang disebut dengan kepercayaan pelayaran ( 7 hari kematian). Penelitian ini bertujuan untuk mengetahui asal usul dari kepercayaan pelayaran 7 hari kematian di Desa Sukarema, Penelitian ini menggunakan metode kualitatif. Tahapan pencarian sumber data dilakukan melalui observasi, wawancara, dan dokumentasi. Analisis yang digunakan dalam penelitian ini adalah analisis data bersifat induktif melalui tahaoan reduksi daya, penyajian data, dan penarikan kesimpulan. Asal usul kepercayaan pelayaran 7 hari kematian berasal dari nenek moyang masyarakat Sasak yang menjadi adat istiadat di desa Sukarema. Kebiasaan ini masih eksis sampai sekarang, karena pelayaran merupakan adat-istiadat yang diwariskan secara turun temurun oleh leluhur atau nenek moyang masyarakat desa Sukarena. Mereka sangat menjunjung tinggi adat istiadat nenek moyang yang sudah ada.
\end{abstract}

Kata Kunci: Eksistensi, Pelayaran, Sejarah

\begin{abstract}
Culture has its own form in a society. In Sukarena Village, East Lombok, there is a custom of the community in respecting the deceased's family, which is called the sailing belief (7 days of death). This study aims to determine the origin of the belief in the 7day death voyage in Sukarema Village. This study uses a qualitative method. The stages of searching for data sources were carried out through observation, interviews, and documentation. The analysis used in this research is inductive data analysis through power reduction, data presentation, and conclusion drawing. The origin of the belief in the 7-day death voyage comes from the ancestors of the Sasak people who became a custom in the village of Sukarema. This habit still exists today, because sailing is a tradition that has been passed down from generation to generation by the ancestors or ancestors of the Sukarena village community. They really respect the traditions of their ancestors that already exist.
\end{abstract}

Keywords: Existence, Sailing, History

\section{Pendahuluan}

Indonesia merupakan negara yang dikenal sebagai Bangsa yang majemuk. Kemajemukan Bangsa karena adanya kemajemukan etnis (suku bangsa). Disamping 
itu, kemajemukan dalam ras, agama, golongan, tingkat ekonomi dan gender. Beragamnya etnik di Indonesia menyebabkan banyak ragam budaya, tradisi, kepercayaan dan pranata kebudayaan yang lain. Masyarakat Indonesia adalah masyarakat multikultural artinya banyak memiliki kebudayaan.

Budaya Sasak Lombok adalah yang sudah menjadi kebiasaan yang melipputi pengetahuan, kepercayaan, kesenian, moral, hukum, adat-istiadat, kebiasaan serta kemampuan lain yang diperoleh dalam kehidupan masyarakat Sasak Lombok. Tradisi budaya Sasak merupakan suatu cara tata cara hidup masyarakat suku Sasak yang berkembang dan dimiliki bersama oleh sebuah kelompok orang dan diwariskan dari generasi kegenaris (Sudirman dan Bahri, 2017, 434-435).

Desa Sukarema merupakan salah satu desa yang berada disebelah selatan kecamatan aikmel, di Kabupaten Lombok Timur yang memiliki kebudayaan yang bersifat unik yang menjadi ciri khas tersendiri yaitu, tentang eksistensi pelayaran (7 hari kematian) di Desa Sukarema. Peneliti akan mengkaji lebih dalam lagi bagaimana sistem kehidupan masyarakat Sasak pada masa lampau serta tatanan yang terbentuk pada masa itu, tentang nilai-nilai leluhur kehidupan bermasyarakat, kaitanya dengan perubahan pola kehidupan pada masa sekarang. Oleh karena itu bila dicermati eksistensi pelayaran (7 hari kematian) sebuah foklor (cerita rakyat) pada masyarakat suku Sasak menyajikan berbagai sisi kehidupan nyata terkait subjektifitas manusia pada masa lampau yang dicirikan dalam cerita dan kepercayaan.

Fakta sosial mengenai kepercayaan akan pelayaran (7 hari kematian) masih banyak dijumpai pada masyarakat Indonesia walaupun dalam era globalisasi sekarang ini serba rasional, eksistensi upacara pelayaran dalam lingkungan masyarakat menjadi diskusi menarik, disamping sebagai warisan budaya juga sebagai wujud analisa relevansi zaman sekarang, kepercayaan tentang upacara pelayaran (7 hari kematian) yang dikompirmasikan dengan zaman modern dan globalisai sebagai slah satu cara pikir dan prilaku yang berkembang di masayarakat yang mempercayai pelayaran (7 hari kematian) tersebut.

Pelayaran (7 hari kematian) lahir dari kehidupan nenek moyang masyarakat di Desa Sukarema upacara pelayaran (7 hari kematian) puncak upacara kematian yang dilaksanakan oleh masyarakat Sasak di Desa Sukarema dan diharuskan upacara pelayaran (7 hari kematian) ini dilaksanakan oleh keluarga yang ditinggalkan oleh 
keluarga yang meninggal. Dimana pelayaran ini dilaksanakan sebagai pelengkap dari apa yang akan kita terima dikemudian hari yang sudah lama dan selalu diadakan setelah kematian dengan upacara tengah malam kira-kira jam 3/4 dilaksanakan hal yang menarik dari fenomena sosial ini yakni masih dipercayai pada kalangan masyarakat Sasak.

Kebudayaan memiliki bentuk tersendiri dalam suatu masyarakat. Di Desa Sukarena Lombok Timur terdapat kebiasaan masyarakat dalam menghormati keluarga yang sudah meninggal dunia yang disebut dengan kepercayaan pelayaran (7 hari kematian). Penelitian terkait seperti di atas, beberapa sudah dilakukan seperti penelitian Busyairy (2018) tentang akulturasi budaya dalam upacara kematian masyarakat kota santri Kediri Lombok Barat. Kemudian ada penelitian Kusnawati (2015) tentang perspektif hukum Islam terhadap praktek sedekah dalam adat kematian Sasak di Desa Karang Bayan Kecamatan Lingsar. Kedua penelitian di atas memiliki perbedaan dengan kajian ini jika dilihat dari aspek upacara kematian pada bentuk yang dilakukan. Penelitian ini lebih kepada aspek ritual budaya yang dilakukan masyarakat desa Sukarema Lombok Timur. Oleh karena itu keberbedaan penelitian ini dengan penelitian sebelumnya dapat dilihat pada aspek ritual budaya yang dilakukan. Adapun tujuan enelitian ini adalah untuk mengetahui asal usul dari kepercayaan pelayaran 7 hari kematian di Desa Sukarema Lombok Timur.

\section{Metode Penelitian}

Metode penelitian ini menggunakan metode kualitatit dengan pendekatan etnografi. Posedur penelitian yang menghasilkan data deskriptif berupa kata-kata tertulis atau lisan dari orang dan pelaku yang dapat diamati, pendekatan ini diarahkan pada latar dan individu atau organisasi-organisasi ke dalam variabel atau hipotesis, tetapi perlu memandangnya sebagai bagian dari suatu keutuhan (Moleong, 2004: 3). Sumber data adalah subjek dari data yang diperoleh (Arikunto, 2006:126) melalui observasi, wawancara, dokumentasi, dan studi kepustakaan. Sumber diperoleh secara langsung oleh orang yang melaksanakan peristiwa itu, yaitu proses upacara pelayaran (7 hari kematian) di Desa Sukarema Lombok Timur. Teknik pengumpulan dilakukan melalui observasi, wawancara, dan dokumentasi (Usman dan Akbar, 2009: 55; Sugiyono, 2012: 231; Bungin, 2010: 121). Analisis data yang dilakukan melalui 
tahapan reduksi data, penyajian data, dan penarikan kesimpulan/verifikasi data (Sugiyono, 2012: 244).

\section{Pembahasan}

\section{Ganti dengan Profil Desa Sukarema Lombok Timur}

Desa Sukarema merupakan salah satu desa sub wilayah dari pulau lombok, yang mayoritas suku sasak. Menurut data yang diperoleh dari Kantor Desa Sukarema, Keadaan geografis Desa Sukaremamerupakan suatu wilayah yang terdiri dari beberapa dusun yang tergabung menjadi satu wilayah yaitu Desa Sukaremadan merupakan salah satu Desa yang ada di Wilayah kecamatan Aikmel kabupaten Lombok Timur. Dengan batas-batas wilayah Desa Sukarema sebagai berikut:

Sebelah utara : Kalijaga Tengah

Sebelah Selatan : : Lenek Baru

Sebelah Barat $\quad$ : Lenek Lauk

Sebelah Timur $\quad$ : Kalijaga Selatan dan Kalijaga Baru

Desa Sukaremamerupakan daerah yang mempunyai ketinggian 120,193 meter dari permukaan Laut. Desa ini mempunyai curah hujan 14,50 mm serta suhu udaranya mencapai $32,36^{\text {Co }}$ Wilayah Desa Sukarema terdiri dari kekadusan, masingmasing dikepalai oleh kadus yang terdiri dari, Dusun Sukarema Timur, Dusun Sukarema Barat, Dusun Kertasari, Dusun Lendang Kantong. Jumlah penduduk Desa Sukarema yang memeluk agama Islam dimana di Dusun Sukarema Timur 821 jiwa, Dusun Sukarema Barat 815 jiwa, Dusun Kertasar 810 jiwa, dan Dusun Lendang Kantonng 901 jiwa dengan keseluruhan yaitu, 3347 jiwa beragama Islam. Berdasarkan penjabaran di atas dapat dilihat bahwa penduduk Desa Sukarema Kecamatan Aikmel secara keseluruhan beragama islam.

Berdasarkan tingkat pendidikanya, masyarakat Desa Sukarema yang melanjutkan jenjang pendidikanya dari PAUT, TK dari usia 3-6 jumlahnya 152 orang, sedangkan anak dan penduduk cacat fisik dan mental 18 orang, dan yang masih SD/sederajat 660 orang, sedangkan yang masih MTs. 130 orang, SMA 832 orang, dan Perguruan Tinggi rata-rata jumlahnya adalah 302 orang. Penduduk Desa Sukarema semakin berkurang yang buta aksara karna mayoritas pendidiknya sampai sekolah dasar. 
Pulau Lombok merupakan salah satu pulau di kawasan NusaTenggara, diapit oleh pulau Bali di bagian barat dan Pulau Sumbawa di bagian Timur. Luas Pulau ini mencapai $5.435 \mathrm{Km}$. 80\% penduduknya pulau ini terdiri dri suku Sasak dan memeluk agama Islam.Pulau ini merupakan pulau terbesar di Provinsi Nusa Tenggara Barat. Oleh karena itu masyarakat bersama-sama membangun Desa Sukarema agar lebih maju dalam bersaing dengan globalisasi yang akan datang dan memiliki lapangan kerja. Mata pencaharian masyarakat Desa Sukarema perlu juga dipaparkan guna untuk mengetahui keadaan masyarakat setempat. Karena jenis pekerjaan akan mempengaruhi perekonomian masing-masing keluarga yang bersangkutan. Dengan demikian dapat diketahui bahwa sebagian besar penduduk Desa Sukarema Kecamatan Aikmel memiliki mata pencaharian petani 268 orang, buruh 569 orang, perkebunan 13 orang, peternak 12 orang, buruh perikanan 7 orang, TNI/ Polri 2 orang, montir 30 orang, Pegawai Negri Sipil 18 dan guru 50 orang, Ojek 40, pengusaha (wiraswasta) 36 orang. Hal ini berarti bahwa tingkat penghasilan masyarakat Desa Sukarema cukup memadai.

\section{Asal Usul Kepercayaan Pelayaran (7 Hari Kematian)}

Masyarakat suku Sasak pada umumnya semula tradisional, terlihat dari pola pikir yang masih sederhana. Kepercayaan yang tradisional inilah tampaknya yang banyak mempengaruhi semua sendi kehidupan mereka, khususnya yang berkaitan dengan berbagai upacara yang berkembang, termasuk didalamnya upacara kematian. Sedangkan upacara yang diselenggarakan merupakan adat dan tradisi yang berkembang dikalangan masyarakat sasak, yang mungkin antara yang satu dari yang lain, terdapat perbedaan-perbedaan. Di desa Sukarema upacara mituq disebut dengan kata lain "pelayaran" pada hari ketujuh setelah kematian, upacara ini dilakukan keluarga untuk do'a keselamatan arwah yang meninggal dengan harapan dapat diterima disisi Allah yang Maha Esa dan keluarga yang ditinggalkan tabah menerima kenyataan.

Asal usul kepercayaan pelayaran (7 hari kematian) ini dahulunya berasal dari nenek moyang yang sudah mendarah daging menjadi adat istiadat di desa Sukarema. Dalam upacara kematian diadakan namanya pelayaran pada hari ketujuh orang yang meninggal dunia yang berlaku belum tentu berlaku pada desa lainnya yang berkembang di masyarakat Sasak sendiri. Selama adat istiadat itu tidak bertentangan dengan agama Islam, maka kami tetap mengerjakannya dan mempertahankanya bagi generasi 
selanjutnya (Wawancara, Dedi Amrullah, 14 Februari 2017). Dapat dipahami bahwa yang berkembang pada masyarakat merupakan warisan nenek moyang. Ditegaskan bahwa pelayaran yang ada dalam upacara memperingati hari ketujuh orang yang meninggal dunia tersebut dibiarkan berjalan apa adanya karena warisan leluhur dan harus dilestarikan keberadaannya.

Menurut Rauahi, kepercayaan masyarakat terhadap pelayaran tujuh hari kematian berasal dari adat istiadat yang sudah berlaku jauh sebelum kita ada, yang menjadi kebiasaan dalam masyarakat dan meniru apa yang sudah dilakukan oleh nenek moyang kita terdahulu hingga sampai sekarang masih dilakukan bertujuan untuk mendo'akan keselamatan arwah yang meninggal dan memperingati bahwa kelurga yang meninggal dunia sudah tujuh hari didalam kubur (Wawancara, Rauhi, 25 Februari 2017).

Salah satu tokoh masyarakat desa Sukarema yang berpendapat di atas berkeyakinan bahwa asal usul kepercayaan pelayaran itu kita memperingati bahwa keluarga yang meninggal dunia sudah tujuh hari di dalam kubur, dan pada saat itu kondisi tubuh mayit akan hancur atau daging akan terpisah dengan tulangnya. Maka si mayit sangat merasakan kesakititan, oleh sebab itu masyarakat yang ada di desa sukarema mengadakan pelayaran dalam rangka do'a bersama dan kita haadiahkan kepada orang yang meninggal dunia. Eksistensi pelayaran tujuh hari kematian di tengah kehidupan masyarakat modern tentunya sesuatu yang menarik diteliti terutama dari aspek soaial budaya masyarakat itu sendiri. Masyarakat desa Sukarema yang sebagai sub wilayah pulau Lombok yang mayoritas Suku Sasak mempunyai kebiasaan uniq terkait dengan tradisi adat istiadat, saat adanya masyarakat mengalami musibah kematiaan.

Pada dasarnya masyarakat sukarema sebagaimana halnya masyarakat lainnya, menerapkan upacara kematian melalui tiga tahap yaitu tahap awal upacara sebelum penguburan, tahap kedua upacara penguburan dan tahap ketiga upacara setelah penguburan. Beberapa saat setelah kematian seseorang, masyarakat bersama keluarga melakukan berbagai persiapan bagi yang meninggal dengan berkumpul untuk musyawarah siapa-siapa saudara-saudari yang akan diundang dalam rangka pemberitahuan berita duka oleh keluarga kepada kerabatyang rumahnya jauh. Sedangkan semua masyarakat yang ada didesa sukarema tanpa undangan, cukup dengan memberitahukan lewat pengeras suara saja masyarakat akan berdatangan. 
Hari ketujuh dari kematian tersebut yang dianggap sebagai hari yang sangat penting, karena pada hari tersebut diselenggarakan puncak upacara yang berkembang didesa Bayan dan sekitarnya, dalam bentuk pembacaan al-Qur'anul Karim yang di mulai pada waktu fajar (Syakur, 2006:302-303). Dalam upacara kematian dilaksanakan zikiran yang bertempat dirumah kelurga yang sudah ditinggalkan oleh orang yang meninggal dunia dengan dihadiri oleh tokoh masyarakat selama satu sampai kesembilan harinya meninggal dunia dilaksanakan zikiran setelah selesai sholat isya. Sedangkan puncak upacara kematian pada hari ketujuh yang dinamakan pelayaran yang dilaksanakan pada tengah malam sekitar jam tiga atau empat dengan mengudang Tuan guru, tokoh agama dan tokoh masyarakat khusunya laki-laki untuk zikiran dan mendo'akan orang yang sudah meninggal dunia.

Semua perubahan itu lebih banyak didasarkan pada pertimbangan agama upacaraupacara sesudah penguburan, seperti hari ketiga disebut nelung, hari ketujuh disebut mituq/pelayaran, hari kesembilan disebut yiwaq, hari keempat puluh disebut metang dasa ,hari keseratus disebut nyatus, hari keseribu disebut nyiu, masih tetap berlaku tetapi lebih didekatkan pada ritual agama berupa do'a dan zikir. Pandangan ini merupakan bentuk akulturasi dalam budaya dan agama yang memang banyak ditemukan dalam kehidupan masyarakat di Lombok secara umum (Busyairy, 2018).

\section{Pandangan Masyarakat Tentang Pelayaran (7 Hari Kematian)}

Masyarakat suku Sasak mempercayai bahwa ada tahapan-tahappan tertentu dalam perjalanan hidup manusia yang dipandang sebagai masa kritis. Pada saat-saat demikian,individu yang bersangkutan dipandang sangat riskan dan ia berada dalam masa transisi dari satu kehidupan ke tahap kehidupan selanjutnya (Zakaria 1998). Pandangan masyarakat dalam eksistensi pelayaran (7 hari kematian) sebagai masyarakat yang memilih kebudayaan yang berkembang sebagai adat istiadat yang sudah ada sejak nenek moyangnya terdahu sebelum kita. Hal ini masih dilaksanakan sampai sekarang, dan merupakan bukti kalau upacara pelayaran pada hari ketujuh kematian masih diterima sangat baik oleh masyarakat desa Sukarema dalam menjalin kekeluargaan dan mempererat persaudaraan antara sesama, seperti belangar, memandikan, penguburan, nelung, mituq, pelayaran, nyiwaq, metang dasa, nyatus, dan nyiu.

Masyarakat Desa Sukarema merupakan Desa yang mayoritas penduduknya 
sebagai petani, dan bahkan sebagai buruh tani dan masih ada juga orang tua yang tidak mengenyam pendidika yang buta huruf yang menyebabkan pola pikir mereka dibentuk oleh nilai budaya nenek moyang. Apabila ditanya pandangan masyarakat tentang pelayaran (7 hari kematian) di desa Sukarema Lombok Timur. Hal ini sebagaimana dijelaskan oleh informan bahwa:

Pandangan saya selaku masyarakat tentang eksistensi pelayaran (7 hari kematian) ini yaitu, Selama hal tersebut tidak merugikan asyarakat itu sendiri biarkan saja berkembang dan berjalan apa adanya toh itu merupakan kepercayaan masyarakat yang menjadi adat istadat yang ada didesa Sukarema dan merupakan adat istiadat yang diwariskan secara turun temurun oleh leluhur atau nenek moyang kita (Wawancara, Abdul Syakur, 17 Februari 2017).

Dalam pandangan informan diatas merupakan wacana yang berkembang pada masyarakat dan merupakan Warisan Nenek moyang, yang masih ada sampai sekarang dan di tegaskan bahwa pelayaran (7 hari kematian) tersebut dibiarkan berjalan apa adanya karena warisan Leluhur dan harus dilestarikan keberadaanya walaupun sulit untuk dibuktikan kebenaranya. Dijelaskan oleh Indriani bahwa:

Saya merupakan masyarakat biasa apabila ditanya tentang hal ini kami tidak bisa menjawab dan kami hanya bisa menjawab biarkan sajatoh merupakan warisan nenek moyang,karena itu sudah menjadi kebiasaan dari nenek moyang yang sudah lama dilaksanakan dan ditiru oleh nenek moyang sebelum kita, menjadi turun temurun sehingga perlu dilestarikan keberadaannya (Wawancara, Indriani, 20 Februari 17).

Dalam pandangan di atas eksistensi pelayaran (7 hari kematian) dimana masyarakat masih memeilih kebudayaan yang berkembang sebagai adat istiadat yang sudah ada sejak nenek moyangnya dahulu. Selama itu tidak menyimpang dan masih dilaksanakan sampai sekarang, itu sebagai bukti kalau upacara pelayaran pada hari ketujuh kematian masih diterima sangat baik oleh masyarakat desa Sukarema dalam menjalin kekeluargaan dan mempererat persaudaraan antara sesama. Jadi pemahaman pelayaran tujuh hari kematiaan sebagaimana yang dimaksud jelas bahwa semakin maju keadaan sosial keagamaan suatu masyarakat, maka semakin maju pula tradisi dan adat-istiadatnya, dalam kenyataannya selalu mengalami perubahan dari zaman ke zaman dari generasi kegenerasi. Perubahan tersebut baik adat istiadat maupun dalam upacara pelayaran karena atas tuntutan situasional dan kondisional yang menyertainya, akan mengarah kepada kesederhanaan dan mendekati yang benar. 


\section{Faktor-faktor yang Mempengaruh Eksistensi Pelayaran (7 Hari Kematian)}

Dalam siklus kehidupan manusia, peristiwa kematian merupakan akhir kehidupan seseorang didunia fana ini. Tidak seseorang pun dari kalangan manusia tersebut yang luput dari peristiwa kematian itu, baik yang sudah tua, yang masih muda, bahkan juga yang masih kecil. Sebagai umat yang beragama khususnya agama islam, masyarakat Sasak secara keseluruhan, boleh dikatakan meyakini akan adanya kehidupan lain sesudah kehidupan didunia, seperti kehidupan di alam barzah atau alam kubur dan kehidupan dialam akhirat.

Kebudayaan sebagai sistem kepercayaan/religi berfungsi sebagai pengarah danpedoman bagi tingkah laku manusia dalam menjalani dan menginterpretasikan berbagai pengalaman mereka sebagai warga dari komunitas dan kesatuan sosialnya. Juga dalam proses bertahannya upacara pelayaran sampai saat ini pada masyarakat Desa Sukarema yakni sistem pengetahuan ini di dapat melalui proses belajar, belajar dari apa yang diberikan oleh alam maupun belajar melalui proses pewarisan.

Menurut penjelasan informan bahwa faktor-faktor yang mempengaruhi eksistensi pelayaran (7 hari kematian) masih diyakini didesa sukarema yaitu: Masyarakat sukarema memegang erat kebudayaan yang ada di masyarkat sukarema, masyarakat Desa sukarema menjunjung tinggi budaya nenek moyang apalagi tentang pelayaran 7 hari kematian ini, masyarakat sukarema berkeyakinan bahwa do'a yang kita baca dan kita hadiahkan kepda orang yang mati, itu akan sampai atau diterima. Jika tidak dilaksanakan upacara pelayaran 7 hari kematian ini akan berpengaruh terhadap orang yang sudah meninggal dunia dan orang yang ditinggalkannya merasa tidak menjalankan kewajiban yang sudah diadakan selama ini (Wawancara, Munsiin, 20 Februari 2017).

Informan lain juga menjelaskan bahwa faktor-faktor yang menyebabkan pelayaran ini masih diyakini sampai sekarang yaitu, tingkat kekeluargaan dan rasa solidaritas yang sangat tinggi dan menjunjung tinggi adat istiadat nenek moyang yang masih kental dalam masyarakat dan adat istiadat tersebut masih dipertahankaan sampai sekarang (Wawancara, H. Hasan Basri, 17 Februari 2017). Faktor-faktornya yang masih berlaku sampai sekarang di sebabkan oleh masyarakat masih menjalankan upacara pelayaran ini, selama inikeluarga yang ditinggalkan dengan hati ikhlas selalu menjalankan upacara pelayaran dalam rangka memperingati hari ketujuh orang 
meninggal dunia, karna tidak melupakan adat istiadat dari nenek moyang dan masih mempertahankan eksistensi pelayaran tujuh hari kematian ini dengan baik (Wawancara, Jamuddin, 17 Februari 2017).

Dalam penuturan beberapa informan di atas, faktor-faktor yang mempengaruhi eksistensi pelayaran (7 hari kematian) masih diyakini di desa Sukarema sampai sekarang disebabkan oleh masyarakat memegang teguh adat istiadat mereka dan menjalankan upacara pelayaran tersebut jika ada yang mendapatkan musibah dalam kehidupan ini. Bagi masyarakat pedesaan tradisional adat istiadat keagamaan memiliki daya pengikat tersendiri. Meninggalkan tradisi berarti mengancam kelanggengan eksistensi masyarakat. Islam yang hidup dalam masyarakat tentu harus mampu bergulat dengan adat istiadat tradisional yang umumnya bersendi pada kepercayaan upacara kematian. Adat istiadat upacara dalam kematian berperan layaknya fungsi agama, tetapi tidak menggantikan agama itu sendiri. Dikatakan demikian karena upacara pelayaran adalah kewajiban bagi keluarga yang ditinggalkan.

Fungsi dan nilai pelayaran tujuh hari kematian bagi masyarakat desa Sukarema, berkeyakinan nasi pelayaran disajikan setiap waktu makan dari hari pertama sampai hari kesembilan. Menurut kepercayaan orang Sasak pada dasarnya roh yang telah keluar dari jasadnya tidak langsung meninggalkan rumah tetapi sampai hari kesembilan masih tetap disekitar rumah dan dia perlu makan minum seperti ketika masih hidup dan disugukan dupa didekatnya. Bekas nasi sajian itu dapat dimakan oleh anak isteri atau suaminya atau kerabatnya yang lain. Di Samping upacara perkawinan, dikenal pula adanya upacara kematian di kalangan suku Sasak salah satunya didesa sukarema. Upacara pelayaran dilakukan oleh hampir semua masyarakat yang mengalami musibah dalam memperingati hari tujuh meninggalnya seseorang, sebagaimana yang berkembang pada umumnya di kalangan masyarakat Sasak.

Menurut Informan pelaksanaan upacara pelayaran dalam pekembangan selanjutnya, masih dilakukantapi lebih disederhanakan, bila dibandingkan dengan yang terjadi pada masa dulu, kecuali di kalangan mereka yang masih kuat menerapkan adat istiadat tersebut. Tokoh yang berperan penting dalam proses pelaksanaan upacara pelayaran adalah Tuan Guru, tokoh agama, keluarga dan masyarakat dan biasanya jamaah yang laki-lai. Dalam rangka proses mulai dari zikiran dan berdo'a dipimpin oleh Tuan Guru, dan jika berhalangan bisa digantikan oleh tokoh agama yang lain. 
Tidak semua upacara kematian suku Sasak melaksanakan adat istiadat tersebut dan upacara tersebut juga tidak sama antara satu daerah dengan daerah lainya, seperti di DesaSukarema dilakukan upacara pelayaran dalam memperingati hari ketujuh orang meninggal dunia dilakukan pada malam hari sekitar pukul 03.50 Wita. Saat ini di Desa Sukarema mayoritas berpendidikan Islam. Tradisi upacara pelayaran ini masih ada, tetapi generasi muda jarang yang mengerti dan bertanya pelayaran itu apa dan dilaksanakan pada hari keberapa, dari sebab itu meskipun dahulu sampai sekarang dilaksanakan masih ada yang belum mengetahuinya. Oleh karena itu eksistensi pelayaran dipertahankan dan diperkenalkan keberadaannya bagi masyarakat.

Peran pemerintah dalam mendukung masyarakatnya untuk melestarikan eksistensi pelayaran pada upacara kematian dalam rangka hari ketujuhnya meninggal dunia, sangat penting dan mengikut sertakan anak muda dalam rangka upacara pelayaran dengan keikutsertaannya bertujuan memperkenalkan kebudayaan yang ada pada masyarakat desa sukarema yang harus dijaga eksistensinya oleh generasi muda dan dibutuhkan peran orang yang mengerti adat istiadat serta dorongan masyarakat yang lebih dulu ada dan mengerti tengtang upacara pelayaran.

Dalam pandangan peneliti ini, hal ini merupakan salah satu bentuk tindakan sosial bertujuan tradisional dari salah satu informan di desa Sukarema. Makna dalam pelayaran tujuh hari kematian merupakan salah satu unsur dari sebuah tanda di samping memiliki makna juga memiliki petanda. Perlunya sebuah tanda dalam diri individu sebagai referensi diri dalam kehidupan dengan hal itu mereka merasa menjadi bagian dari anggota masyarakat itu. Pelayaran sebagai sebuah sistem kepercayaan religi ini masuk dalam ciri khas kebudayaan ke dalam tiga wujudnya, seperti kebudayaan dalam wujud fisik, kebudayaan sebagai sistem sosial, dan kebudayaan sebagai sistem budaya. Artinya simbolisasi diperlukan oleh individu, kebudayaan dalam wujud fisik dapat terlihat dari hasil-hasil kebudayaan (Koentjaraningrat, 1993).

Suasana filosofis yang agak jernih ini di mana dunia dilihat sebagai sesuatu yang diciptakan oleh bahasa. Nampaknya mungkin agak aneh, padahal kenyatanya kita sudah menemukan fikiran dalam suatu cara yang berbeda dalam varian teori tindakan yang paling mutakhir, etnometodologi (Susanto,2012). Upacara pelayaran ketujuh hari kematian merupakan medium yang sangat subjektif, tergantung kepada misi dan visi pesan-pesan yang ingin disampaikan. Adakalanya berupa pesan kepercayaan, pesan- 
pesan agama dan moral. Dengan demikian selama pesan-pesanya positif bagi masyarakat desa Sukarema, dan membagun rasa solidaritas dalam hidup bermasyarakat, jadi tidak ada perbedaan dalam lingkugan tertentu.

Di atas telah diuraikan secara rinci bagaimana sifat dan karakter Suku Sasak dan kebiasaan masyarakat desa Sukarema sebagai bagian dari suku Sasak sangat terbuka dan menghormati adat istiadat baik itu berupa ritual, kesenian ataupun yang lainnya. Apalagi hal itu merupakan peninggalan dari nenek moyang mereka sendiri, seperti upacara pelayaran dalam memperingati tujuhhari kematian pada masyarakat Suku Sasak di kuatkan dengan mayoritas penduduk suku Sasak yang bekerja di bidang agraris serta karakter yang menerima dan semakin mendukung eksistensi ini sendiri.

\section{Kesimpulan}

Pelayaran yang diupacarakan oleh nenek moyang secara historis pada dasarnya dihasilkan oleh proses hidup manusia terhadap lingkungan dan kehidupannya. Pada saat manusia berinteraksi dengan lingkungan dan aspek kehidupan lainnya. Pandangan masyarakat tentang eksistensi pelayaran (7 hari kematian) ini selama tidak merugikan masyarakat itu sendiri biarkan saja berkembang dan berjalan apa adanya. Faktor-faktor yang mempengaruhi eksistensi pelayaran (7 hari kematian) masih diyakini oleh masyarakat karena tingkat kekeluargaan dan rasa bersama dalam membangun suatu hubungan yang sangat baik, menjunjung tinggi adat-istiadat dan memegang erat kebudayaan yang ada terutama tentang pelayaran tujuh hari kematian ini. Pelayaran tujuh hari kematian ini berasal dari adat istiadat dari nenek moyang kita dahulu dan masih berlaku hinggga sekarang. Menyikapi semua hal baik itu berupa adat-istiadat ataupun kepercayaan yang menyebar dalam suatu masyarakat. Eksistensi pelayaran tujuh hari kematian memiliki makna hal-hal seperti membawa manfaat pemersatu persepsi dan nilai dari masyarakat, dan juga menyikapi dunia modern, globalisme yang semakin hari menuntut perubahan-perubahan yang tidak substasial dan sangat materialis. Mengungkap kembali warisan budaya nenek moyang dalam bentuk apapun itu perlu dilandasi permikiran rasional agar lebih berimbang. Semoga apa yang menjadi karya peneliti ini menjadi sebuah alternatif dalam menyikapi dan memahami fenomena sosial budaya yang tiada henti. 


\section{Daftar Rujukan}

Bungin, Burhan. (2010). Penelitian Jualitatif. Jakarta: Kencana

Busyairy, L. A. (2018). Akulturasi Budaya dalam Upacara Kematian Masyarakat Kota Santri Kediri Lombok Barat. Harmoni, 17(2), 228-243.

Koentjaraningrat, (1993). Kebudayaan, Mentalitas dan Pembangunan. Jakarta: Gramedia Pustaka Utama.

Kusnawati, (2015). Perspektif Hukum Islam Terhadap Praktek Sedekah dalam Adat Kematian Sasak di Desa Karang Bayan Kecamatan Lingsar. Mu'amalat, 7(1), 2745.

Moleong, Lexy, J. (2013). Metodologi Penelitian Kualitatif. Bandung: PT Remaja Rosdyakarya.

Profil Desa Sukarema Tahun 2016

Sapardi, Saheh. (2001). Atraksi Budaya Kabupaten Lombok Timur. Lombok Timur: Agenda, www.google.com.

Sudirman dan Bahri. (2014). Studi Sejarah dan Budaya Lombok. Lombok Timur: Puskanda

Sugiyono. (2012). Metode Penelitian Kuantitatif, Kualitatif, dan R\&D. Bandung: Alfabeta.

Susanto, Happy. (2012). Filsafat Ilmu: Telaah Kritis Atas Hakekat dan Cara Kerja Ilmu Pengetahuan. Ponorogo: P2MP Spectrum Press Ponorogo.

Syakur, Ahmad Abd. (2006). Islam dan Kebudayaan Alkulturasi Nilai-nilai Islam dalam Budaya Sasak. Yogyakarta: Adab Press.

Wawancara, Abdul Syakur, 17 Februari 2017

Wawancara, Dedi Amrullah, 14 Februari 2017.

Wawancara, H. HasanBasri, 17 Februari 2017.

Wawancara, Indriani, 20 Februari 17

Wawancara, Jamuddin, 17 Februari 2017.

Wawancara, Munsiin, 20 Februari 2017.

Wawancara, Rauhi, 25 Februari 2017.

Zakaria, Fathurrahman. (1998). Mozaik Budaya Orang Mataram. Mataram: Sumurmas Al-Hamidy. 